\title{
Organizational knowledge based on ISO 9001: 2015 in a higher education institution
}

\section{Conocimiento organizacional con base a ISO 9001:2015 en una institución de educación superior}

FORNÉS-RIVERA, René Daniel †*, CANO-CARRASCO, Adolfo, CHAN-GARCÍA, David Leobardo and VÁSQUEZ-TORRES, María Del Carmen

Instituto Tecnológico de Sonora, Departamento de Ingeniería Industrial, Campus Náinari, Ciudad Obregón, Sonora

ID $1^{\text {st }}$ Author: René Daniel, Fornés-Rivera / ORC ID: 0000-0002-7438-0056, Researcher ID Thomson: G-3906-2018, arXiv Author ID: rene_fornes, CVU CONACYT ID: 280435

ID $1^{\text {st }}$ Co-author: Adolfo, Cano-Carrasco / ORC ID: 0000-0002-3392-3667, Researcher ID Thomson: G-5035-2018, arXiv Author ID: adolfo. cano, CVU CONACYT ID: 276064

ID $2^{\text {nd }}$ Co-author: David Leobardo, Chan-García / ORC ID: 0000-0002-4007-7382, Researcher ID Thomson: David Chan, arXiv Author ID: Leobardo Chan

ID $3^{\text {rd }}$ Co-author: María Del Carmen, Vásquez-Torres / ORC ID: 0000-0003-0938-4955, Researcher ID Thomson: X2104-2018, CVU CONACYT ID: 286266

DOI: $10.35429 / J P D .2021 .14 .5 .32 .40$

Received July 25, 2021; Accepted December 30, 2021

\section{Abstract}

The purpose of the research was the implementation of a methodology to determine the organizational knowledge of the key processes of the areas of Cultural Extension, Sports Extension and Coordination of Academic Development, of a Higher Education Institution, given the need to achieve recertification in ISO 9001: 2015, in compliance with requirement 7.1.6 called organizational knowledge. The procedure was: identify the knowledge, acquire that knowledge, develop the knowledge, transfer the knowledge and use that knowledge. The objective was to generate evidence through an organizational knowledge methodology for the compliance of requirements oriented to the fulfillment of organizational knowledge stipulated in section 7.1.6 of the standard; The findings being a contribution to the recertification achieved in 2018; Through achieving a broad vision in the approach of each area in question; and in knowing how current knowledge is leveraged in each of its eleven key skills.

Knowledge management, Organizational knowledge, Knowledge transfer

\begin{abstract}
Resumen
El propósito de la investigación fue la implementación de una metodología para determinar el conocimiento organizacional de los procesos clave de las áreas de Extensión Cultural, Extensión de Deportes y Coordinación del Desarrollo Académico, de una Institución de Educación Superior, dada la necesidad de lograr la recertificación en ISO 9001:2015, en cumplimiento del requisito 7.1.6 denominado conocimiento organizacional. El procedimiento fue: identificar el conocimiento, adquirir ese conocimiento, desarrollar el conocimiento, transferir el conocimiento y utilizar ese conocimiento. El objetivo fue generar evidencia a través de una metodología de conocimiento organizacional para la conformidad de requisitos orientados al cumplimiento de conocimiento organizacional estipulado en el apartado 7.1.6 de la norma; siendo los hallazgos un aporte en la recertificación alcanzada en el año 2018; a través de lograr una visión amplia en el abordaje de cada área en cuestión; y en saber cómo se aprovecha el conocimiento actual en cada uno de sus once conocimientos clave.
\end{abstract}

Gestión del conocimiento, Conocimiento organizacional, Transferencia de conocimiento

Citation: FORNÉS-RIVERA, René Daniel, CANO-CARRASCO, Adolfo, CHAN-GARCÍA, David Leobardo and VÁSQUEZ-TORRES, María Del Carmen. Organizational knowledge based on ISO 9001: 2015 in a higher education institution. Journal Practical Didactics. 2021, 5-14: 32-40

*Correspondence to Author (e-mail: rene.fornes@itson.edu.mx)

$\dagger$ Researcher contributing as first author. 


\section{Introduction}

The organizational evaluation of the university is a social function with improvement purposes; To approach Knowledge Management (CG), resulting in Organizational Knowledge (OC) in Higher Education Institutions (HEI), it is essential to evaluate the management of intellectual assets based on the importance that the development of knowledge provides to society specialized from HEIs. That is why Obeso et al., (2013), and Cantón and Ferrero (2016) argue that globalization and the use of information technologies to which today's society is subjected gives rise to increased competition in markets around the world, and what produces wealth is no longer access to raw materials or financial resources; but rather the ability to apply knowledge, resulting in the search for efficiency, in such a way that QA has been identified as a fundamental tool for conveniently managing an organization's knowledge, emphasizing its importance in labor mobility, which can cause that knowledge that is only the domain of a person can be lost if it is not transferred in a timely manner.

Soulejman-Janu (2016) asserts that an expert organization in creating, acquiring and transferring knowledge and in modifying behavior reflects the management of $\mathrm{OC}$, in this way they exhibit five main characteristics; personal mastery, mental models, a shared vision, team learning and systematic thinking. Krogh et al., (2011) and Pérez-Soltero et al., (2017) and Torres-Nevares (2014), indicate that $\mathrm{GC}$ is a strategic resource that is transforming the forms of competition, the process of strategy development and decision making. of decisions. $\mathrm{KM}$ is a process of transforming information and intellectual assets into lasting value, it is the ability of a company to increase tacit knowledge, being the one that is used intuitively, and unconsciously, it is in the mind of the individual and that is acquired through experience itself, characterized by being personal and contextual (Pérez-Fuillerat et al., (2019) and Hernández (2016).

While explicit knowledge is that which is structured, has form and is systematic. articulated, expressed and recorded with words, numbers, images, codes, universal principles, scientific formulas, etc.
Your information is usually stored in documents, procedures, programs, processes, manuals, specifications, tutorials or in databases (Aranda-Díaz, 2018; Cantón and Ferrero, 2016 and Hernández, 2016). Regarding the transformation of knowledge into information, Cantón and Ferrero (2016) approach it under an organizational approach. ional, since this knowledge is produced between the people of the organization (human capital, relational capital and intellectual capital).

They argue that, although a computer is capable of capturing and transforming data into information, only the human being can convert that data and that information into knowledge and in turn learn from it, so, in all this process, it is necessary to go from the information management to the GC. It is the ability of a company to increase tacit knowledge and create the preconditions for the exchange of information among employees, being an organized process, of creation, capture, storage, dissemination and use of knowledge within and between organizations to maintain the competitive advantage (Giraldo, 2018).

For Fornes-Rivera et al., (2017) and Ontiveros (2018), KM is the ability to organize and create new knowledge, disseminate and encapsulate it in products, services, systems and the organization of these knowledge flows, tacit and explicit, is a dynamic that occurs through a process of exchange and dialogue in the broad sense of the term. For (Pereira-Alfaro 2011; Hernández, 2016; Giraldo, 2018; Velázquez, 2017 and Canteli, 2019). It is the orderly and systematic process that allows to detect, select, organize, filter, present and use the information by the participants of the company, to exploit in an articulated way the knowledge resource based on the intellectual capital of the organizations, oriented to enhance people's skills and the generation of value.

For Arjona-Villanueva (2014), GC improves processes, employs networks of experts supported by a powerful intranet accessible to all employees, learning lessons in problem solving to improve productivity. 
While KM consists of the process of identifying, capturing, organizing and using the means to create and maintain a competitive advantage; A QA system allows intangible information to be managed as an organizational asset, as if it were tangible (Evans and Lindsay, 2020; Krogh et al., 2011; Zavala (2014) and Soulejman-Janu, 2016). Meanwhile the CO, shows the competitive advantages in organizations. In this way, it is defined as a response to change, a complex educational strategy whose purpose is to minimize costs, capture new markets, change the beliefs, attitudes, values and structure of organizations, so that they can better adapt to new trends, positioning in new markets and at the dizzying pace of change, reducing uncertainty and excess competition Evans and Lindsay (2020) and (Nonaka and Takeuchi (1995), cited in Hernández (2016)), the creation of organizational knowledge is the capacity of the company as a whole to create knowledge and disseminate it to the organization and incorporate it into products, services and systems.

Freitas and Yaber (2015) define that Knowledge Management Systems (QMS) as the set of elements that intervene in the QA process, in order to improve the different activities carried out in organizations, and in particular in the IES, this allows optimizing the decision-making process, the creation of a study plan, the development of research, academic and administrative activities, reducing operating costs, and this is how competitive advantages are obtained. For HEIs and Scientific Research Centers, in the knowledge environment, $\mathrm{KM}$ is essential, especially for the researcher, its vision and mission imply, objectively relating the creation, acquisition, retention and transfer of knowledge in a responsible environment, social and cooperation to the development of the integration of knowledge locally and nationally (Barroso-Tanoría, 2011).

At present, there is a consensus that the countries that will have the best chance of developing in the 21 st century will be those that bet on comparative advantages based on the education and qualification of their workforce.
These are what some authors and multilateral organizations have called "knowledge economies", defined by the World Bank as those that are based mainly on the use of ideas instead of physical skills and on the application of technology instead of transformation. of raw materials or the exploitation of labor (Lomelí, 2018). According to Ferreyra et al. (2017) in the search for growth and equity, no country can afford to ignore higher education. Through higher education, a country builds a skilled workforce and builds the capacity to generate knowledge and innovation, which in turn boosts productivity and economic growth. Since the acquisition of skills increases productivity and people's expected income, a good educational system is the basis for achieving greater equity and shared prosperity at the social level.

Another important achievement is that state public universities, in which more than a quarter of all students are enrolled, now have more than $80 \%$ of their undergraduate students enrolled in programs whose quality has been externally accredited. In addition, the creation and expansion of technological and polytechnic universities in the last two decades, and the recent development of distance education, make the offer of higher education now more diverse and better aligned to different profiles of students and needs of the labor market (Gurría, 2020).

In an HEI, the knowledge they generate allows guiding the reorganization of processes, decision-making and the improvement of teaching, research and innovation, in this way, it would be advancing towards the competitiveness of the institution to respond to the demands of the same and external to society, for this reason the institution is registered in a national body of universities (National Association of Higher Education Universities [ANUIES], 2021). In such a scenario, HEIs play a very favorable role in the development of the country, the well-being of people, through the accreditation of educational programs by organizations such as (Council for the Accreditation of Engineering Education [CACEI] 2021), In turn, to improve the effectiveness and efficiency in achieving its objectives, the institution guides its operation through its management by processes, see Figure 1. 


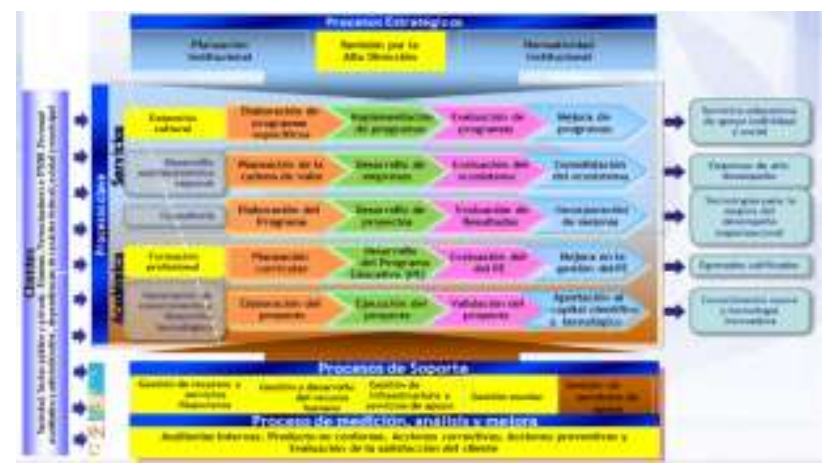

Figure 1 Process-based model of the ITSON QMS Source: ITSON (2021)

Note: this project is within the support processes, specifically in the measurement, analysis and improvement.

The clients are students, academic and non-academic personnel, federal, state and municipal government agencies, as well as the society to which the Institution owes itself. The population served is 17,173 students (ITSON, 2020).

The ISO 9001: 2008 version does not require a section dedicated to the knowledge of the organization, due to this, the institution will have an outdated version of its QMS, thus jeopardizing the recertification by the ISO 9001: 2015 standard. Due to what has been described above, the proposal is made of what action should be carried out in the QMS processes to comply with requirement 7.1.6, determining to generate evidence through an organizational knowledge methodology, for the compliance of the requirement.

\section{Methodology to be developed}

The type of research according to the object under study was applied, as it was focused on finding mechanisms or strategies that allow achieving a specific objective. Consequently, the type of scope to which it applies is very specific and well defined. Due to its depth, it is considered that it was exploratory because it was a first approach that allows later research to be directed to an analysis of the subject matter. Due to the type of data used, the research was qualitative since the data obtained can be worked on at another time in order to be analyzed, making the explanation about the phenomenon studied more complete.
Due to the degree of manipulation of the variables, it is considered non-experimental, and due to the type of inference, the inductive method, and due to the temporality of the study, it is considered longitudinal because the same processes are followed over a specific period of time. ; Hernández-Sampieri, Fernández-Collado and Baptista-Lucio (2014), focusing on the construction of a route consisting of five stages: 1) Identify knowledge; 2) Acquire knowledge; 3) Develop knowledge; 4) Transfer knowledge; and 5) Use knowledge.

The objective was to generate evidence through an organizational knowledge methodology for the compliance of requirements oriented to the fulfillment of organizational knowledge stipulated in section 7.1.6 of the standard. For this, documentary information was specifically reviewed on the processes contained in the institution's SGC, such as: Cultural Extension (EC), Sports Extension (ED) and Academic Development Coordination (CDA), at the same time the process map was assessed of the institution represented through the value chain (Figure 1), in order to analyze and understand the relationship and the impact of the processes and their activations in the generation of key knowledge; Finally, empirical information was collected through a 22-item perception survey to determine key knowledge with response options such as (Always; Almost always; Regularly;

Almost never; and Never) validated by a pilot test and responsible expert consultants. of the institutional QMS to identify organizational capacities in terms of identifying, acquiring, developing, transferring and using key knowledge in the aforementioned processes. The stages were: 1) identification of knowledge; and includes questions 1, 2, 3 and $7 ; 2$ ) acquisition of knowledge; with questions 4, 6, 8, 11 and 12; 3) knowledge development; with questions $5,9,12,14,15$; 4) knowledge transfer; with questions 13,16, 17, 18, 20; and 5) use of knowledge; with questions 19, 21, 22, respectively (Fornés-Rivera et al., (2017) which is supported by the criteria proposed by Nonaka and Takeuchi (1995), cited in Hernández (2016) for the development of knowledge, defined the means and resources to achieve an understanding of the knowledge that was developed. 
Information supported by PereiraAlfaro (2011) as mapping tools were used to align that key knowledge to the information of the investigated areas through indicators and / or goals and information validated by the institutional SGC This survey was applied to one hundred percent of the personnel of the three areas, a total of 62 people including department heads, coordinators of educational programs and internal (plant) and external (auxiliary) personnel, reporting the intention of the study To analyze the data in a first and second application of the instrument, perceptions of the respondents were collated to find areas of opportunity. ad within the organizational structure in relation to OC.

\section{Results}

The information obtained from the implementation of the methodology for the impulse of CO and GC is shown, in the object under study. Note: For the purposes of results and their broadness, only those of the CE area are presented in the first four stages; In the last stage, the results of the two remaining areas are integrated, which are: ED and CDA.

1. Identification of key knowledge: The intervention was in the key process of programming art workshops to the community; which is made up of four activities of the process, composed of the name of the activity, its description and coding, which are:

1. Plan art workshops to the community the programming proposal -001-A is made

2. Plan art workshops for the community spaces and infrastructure are managed 001- B

3. Offer workshops - the promotion of workshops to the community is carried out -002

4. Check the status of workshops - the number of students registered for each workshop is analyzed - 003

Four activities of the key process mentioned above were identified.
2. Acquisition of key knowledge: By identifying the activities that generate key knowledge for the process of programming art workshops to the community, the direct source of that knowledge was obtained as a result, which are:

1. Availability (external and internal)

2. Epistemological (tacit and explicit

3. Ontological (group, individual and organizational)

4. Source (process, person and client)

It was sought to acquire knowledge from the direct source, which is in people, but in some cases the knowledge comes from part of a software, from the client, it was identified that in all activities they are developed in a group way, one depends on external form (an ITSON department), two activities 001-A and 003 were considered tacit as they are not clear but are understood by the context of the description of the activity, none of the activities are of origin by the client and only the activity 001-A is carried out directly by the knowledge of the people.

3. Key knowledge development: The key knowledge was defined, by applying the resource definition format to develop the corresponding area, in which information is appreciated from the people who are involved in the key knowledge defined in the previous step, as well as the people with the work After transferring their knowledge, they determined the means and / or resources to be able to develop, and their schedule of sessions to demonstrate and formalize their development. It continued to describe those responsible, the position they hold and the total number of activities in their charge.

4. Key knowledge transfer: The result was the compilation of necessary information (formats, hierarchies, work instructions, brochures, catalogs, among other supports), for the CE area. See Figure 2. 


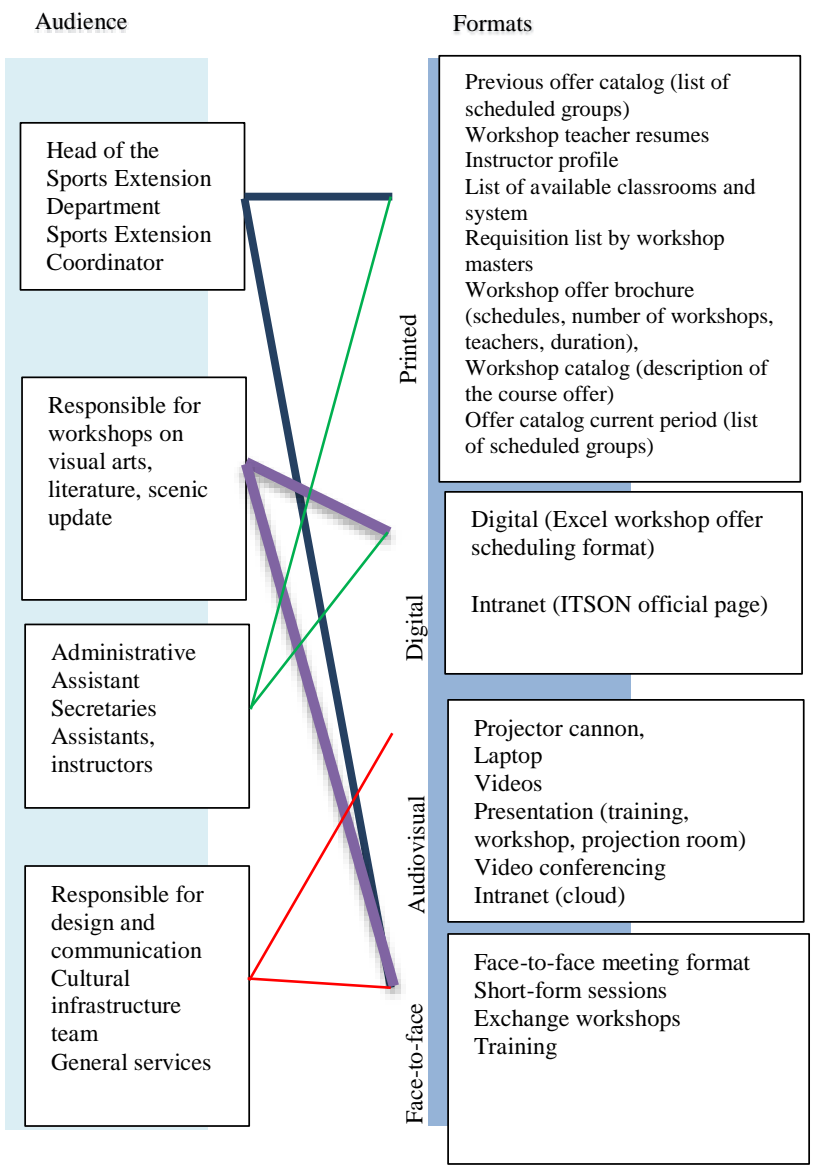

Figure 2 Knowledge transfer model

5. Use of key knowledge: Which was achieved through the application to a total of 62 employees in the three areas EC, ED and CDA, with a survey (explained in the method) carried out before and after the organizational knowledge process, see Graph 1.

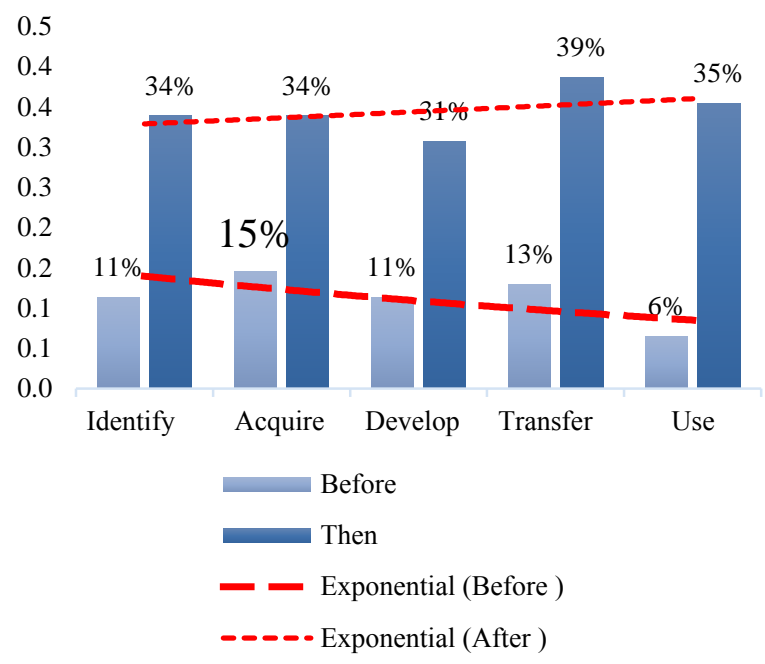

Graphic 1 Organizational knowledge results by stages
In Graphic 1, the result derived from the application of the instrument is shown, showing an increase in organizational knowledge in each of the five stages. In turn, in Graphic 2, the general result is shown in each of the three areas.

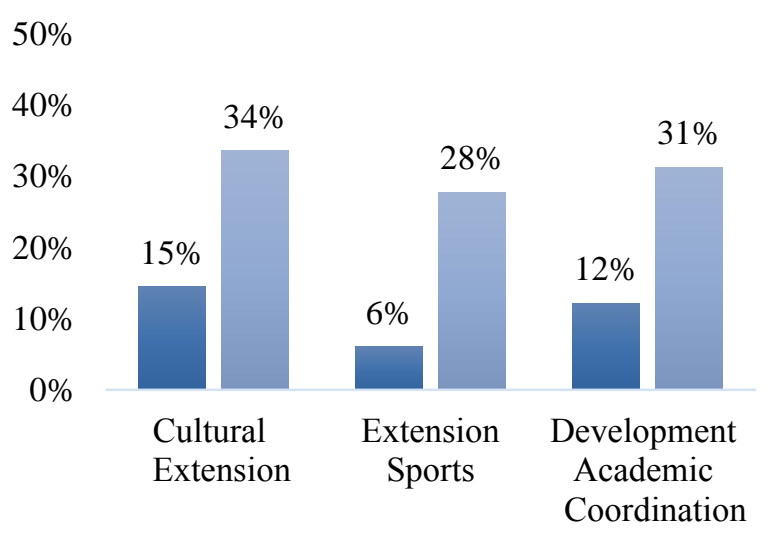

- Prior to the application of the instruments

after the application of the instruments

Graphic 2 General results before and after the ED, EC and CDA areas

Graphic 2 shows the result before and after the application of the instrument, a greater benefit was obtained in ED, with a change from $6 \%$ to $28 \%$; achieving an improvement of $22 \%$; then CDA with a change from $12 \%$ to $31 \%$; achieving an improvement of $19 \%$ and finally EC, with a change from $15 \%$ to $34 \%$; achieving a $19 \%$ improvement in positive perception and knowledge towards the organization. In order to expand what has been done in each area, the key EC process is presented, which was the programming of art workshops to the community, showing its key knowledge:

001 - Define an art workshop offer for the university and general community;

002- Determine the installed capacity and the space requirement;

003- Analyze the level of customer acceptance; 004- Decision-making to open or cancel the workshop.

Key knowledge of the ED area, in its key process of selecting teachers to teach curricular courses:

001- Determination of the programming of courses to schools and academies;

002- Analyze availability of sports offer to courses, schools and academies;

003- Manage the process of payment of fees to staff; 
Key knowledge of the CDA area, in its key process of selecting teachers to teach curricular courses

001-Identify teachers who meet the requirements established in the teacher profile;

002- Determination of requirements that the candidate must meet;

003-Final decision of the requirements that the candidate must meet;

004- Final decision for the selection of highly recommended and recommended candidate. knowledge.

Graphic 3 shows the result for key

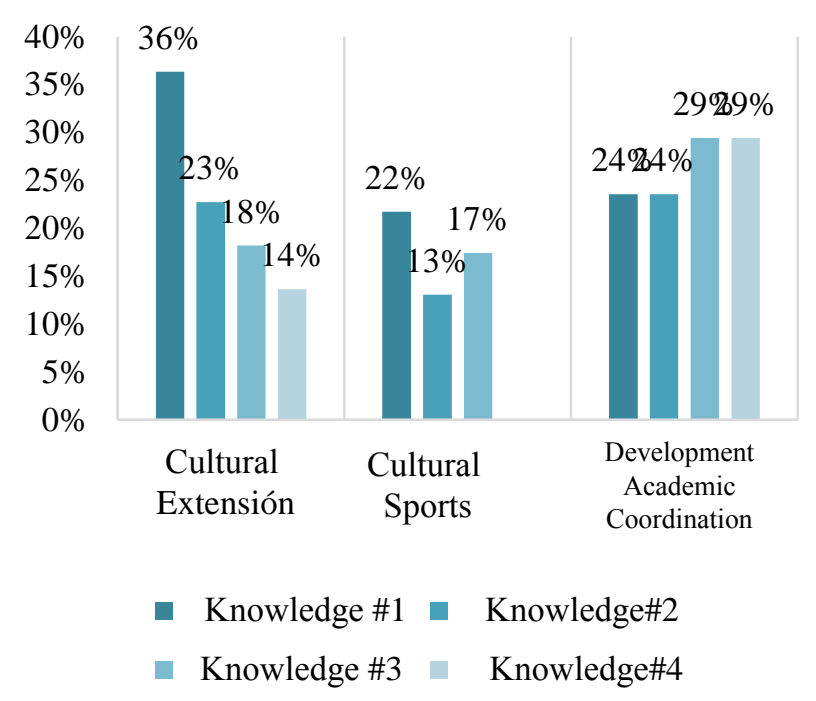

Graphic 3 Change results for each key knowledge detected

Graphic 3 shows the result in each of the three areas studied, specifically at the level of each key knowledge, with the best result being 001 defining an art workshop offer for the university and general community with $36 \%$, in $\mathrm{EC}$; in ED the best was activity 001, determining the programming of courses to schools and academies with $22 \%$; and finally in CDA two key knowledge are observed, 003 final decision of the requirements that the candidate must meet with $29 \%$, and 004 final decision for the selection of highly recommended and recommended candidate with $29 \%$ respectively.

\section{Conclusion}

Organizational knowledge objective was achieved; It contributed to the fulfillment of section 7.1.6 of the standard, the findings being a contribution to the recertification achieved in 2018.
Through achieving a broad vision in the approach of each area in question; and in knowing how current knowledge is used in each of its eleven key knowledge.

\section{Recommendations}

This research gives rise to other studies both in the field of universities or in general in education, as well as in the industrial sector, since activities and processes present in any productive sector are evaluated working with the most valuable thing they have, which is the knowledge of its personnel, which must manage and preserve.

\section{References}

Aranda-Díaz, A. (2018). La gestión del
conocimiento tácito y y explícito.
https://netmind.net/es/gestion-del-
conocimiento-tacito-y-explicito/

Arjona-Villanueva, M. (2014). Calidad y tecnología. 9 de las empresas que mejor han gestionado el conocimiento. http://www.calidadytecnologia.com/2014/05/G estion-Conocimiento-Mejores-Empresas.html

ANUIES. (2021). Directorio Nacional de Instituciones de Educación Superior. ANUIES http://www.anuies.mx/html/diries/index.php

Barroso-Tanoira, F. G. (2011, del 5 al 7 de octubre). Área de Investigación: Formación profesional en contaduría, administración e informática. Gestión del conocimiento en instituciones de educación superior y centros de investigación científica en el estado de Yucatán. [conferencia]. XVI Congreso internacional de contaduría, administración e informática.

México. http://congreso.investiga.fca.unam.mx/docs/xvi/ docs/9E.pdf

CACEI. (2021). Catálogo de Programas Acreditados. CACEI. http://www.cacei.org.mx/nvtu/nvtu03/nvtu0304 01.php

Canteli, A. (2019). Qué es la gestión del conocimiento.

https://www.openkm.com/es/blog/que-es-lagestion-del-conocimiento.html 
Cantón, I., y Ferrero, E. (2016). La gestión del conocimiento en revistas de educación. Universidad de León. Educar 2016, vol. 52/2 401-422

https://ddd.uab.cat/pub/educar/educar_a2016v5 2n2/educar_a2016v52n2p401.pdf

Evans, J. R., y Lindsay, W. M. (2020). Administración y control de la calidad. (10a ed.)

CENGAGE https://latinoamerica.cengage.com/1s/97860752 69269/

Fornés-Rivera, R. D., Cano-Carrasco, A., Reyes-Anaya, J. H., y Valtierra-Navarro, A. J. (2017). Diseño metodológico para el conocimiento de la organización con base a ISO 9001:2015 en una Institución de Educación Superior. Revista de Tecnología de la Información. vol. 4 No.11, 56-69. http://www.ecorfan.org/bolivia/researchjournals /Tecnologias_de_la_Informacion/vol4num 11/R evista_de_Tecnologias_de_la_Informacion_V4 _N11_7.pdf

Freitas, V., y Yaber, G. (2015). Una Taxonomía de los Factores Clave de Éxito en la Implantación de Sistemas de Gestión del Conocimiento en Instituciones de Educación Superior. GECONTEC: Revista Internacional de Gestión del Conocimiento y la Tecnología., Vol.3. (No.1), pp-69-86. https://www.researchgate.net/publication/28103 2153_GECONTEC_Revista_Internacional_de Gestion_del_Conocimiento_y_la_Tecnologia

Ferreyra, M. M., Ciro, A., Botero, J. A. Á., Haimovich, F. P., y Urzúa, S. (2017). Momento decisivo. La educación superior en América Latina y el Caribe. Grupo Banco Mundial. Pp 1 -

59https://openknowledge.worldbank.org/bitstre am/handle/10986/26489/211014ovSP.pdf?sequ ence $=5 \&$ is Allowed $=y$

Gildardo, C. O. (2018). La gestión del conocimiento en las organizaciones y regiones: Una revisión de la literatura. Revista de la Facultad de Ciencias Económicas y Administrativas. Universidad de Nariño. Vol. 19 No.1. $\quad$ Pp. $140-163$ http://www.scielo.org.co/pdf/tend/v19n1/25390554-tend-19-01-00140.pdf
Gurría, A. (2020). Los desafios y oportunidades de la educación superior en México. OCDE. https://www.oecd.org/about/secretarygeneral/challenges-and-opportunities-of-highereducation-in-mexico-january-2020-sp.htm

Hernández, V. (2016). La gestión del conocimiento en las organizaciones. Alfaomega.

https://www.alfaomega.com.mx/default/catalog o/profesional/la-gestion-del-conocimiento.html

Hernández-Sampieri, R., Fernández-Collado, C. y Baptista-Lucio, P. (2014). Definición del alcance de la investigación que se realizará: exploratorio, descriptivo, correlacional o explicativo. En Hernández-Sampieri, R., Fernández-Collado, C. y Baptista-Lucio, P. Metodología de la Investigación (6 ed.). págs. 88-101. McGraw-Hill.

ITSON. (2020). Matrícula atendida. https://www.itson.mx/micrositios/pdi2020/Site Assets/Paginas/informacionindicadores/3.2\%20 Matr\%c3\%adcula\%20atendida.pdf

ITSON. (2021). Cadena de valor. http://biblioteca.itson.mx/oa/oficina_proyectos/ oa1/oa/external/cadena_valor.pdf

Krogh, G. V., Nonaka, I., \& Rechsteiner, L. (2011). Leadership in Organizational Knowledge Creation: A Review and Framework. Journal Of Management Studies. https://doi.org/10.1111/j.14676486.2010.00978.x

Lomelí, V. L. (2018). Educación superior y desarrollo: los desafíos de México. Journal of Economic Literature. Economíaunam vol. 16, No.

http://www.economia.unam.mx/assets/pdfs/eco nunam/47/01Lomeli.pdf

Obeso, M., Sarabia, M., y Sarabia, J. M., (2013). Gestionando conocimiento en las organizaciones: Pasado, presente y futuro. Intangible Capital, vol. 9, No. 4, pp. 1042-1067. Universitat Politécnica de Catalunya. https://www.redalyc.org/pdf/549/54929516005. pdf 
Ontiveros, R. (2018). Evaluación de la percepción del Sistema de Gestión de Calidad de una Institución de Educación Superior: plan de acción. [Tesis de pregrado. Instituto Tecnológico de Sonora]. https://biblioteca.itson.mx/dac_new/tesis/2055. pdf

Pereira-Alfaro, H. (2011). Implementación de la gestión del conocimiento en la empresa. Éxito empresarial No. 135. Pp. 2-6. CEGESTI. http://www.cegesti.org/exitoempresarial/public aciones/publicacion_135_310111_es.pdf

Pérez-Fuillerat, N., Solano-Ruiz, M. C., \& Amezcua, M. (2019). Conocimiento tácito: características en la práctica enfermera. Gaceta Sanitaria. 33(2), 191-196. Epub.

https://www.sciencedirect.com/science/article/p ii/S0213911117303114?via\%3Dihub

Perez-Soltero, A., Llanes-Hoyos, L., BarcelóValenzuela, M., y Sanchez-Schmitt, G. (2017). Modelo estratégico propuesto para transferencia de conocimiento en apoyo a la toma de decisiones en Marketing. Revista de Investigación Académica sin Frontera (25), pp 1-20.

http://revistainvestigacionacademicasinfrontera. com/inicio/

Soulejman-Janu, S. (2016). Becoming a Knowledge-Sharing Organization. Washington, DC: International Bank for Reconstruction and Development / The World Bank Group. https://openknowledge.worldbank.org/bitstream /handle/10986/25320/9781464809439.pdf

Torres-Narváez, M; Cruz-Valencia, I. y Hernández-Jaramillo, J. (2014). Gestión del conocimiento: experiencias de instituciones académicas y hospitalarios. Revista Ciencia y Salud. Vol.12. No. 2, 169-81. https://revistas.urosario.edu.co/index.php/revsal ud/article/view/3076

Velásquez, P. M. (2017). La gestión del conocimiento en la nueva economía. https://www.evaluandoerp.com/conceptogestion-del-conocimiento/
Zavala, A. (2014). Desarrollo $e$ implementación de una estrategia de gestión del conocimiento en una empresa comercializadora. [Tesis de pregrado, Universidad de Sonora]. http://www.repositorioinstitucional.uson.mx/bit stream/handle/unison/707/zavalaguerreroanaga brielm.pdf? sequence $=1 \&$ isAllowed $=\mathrm{y}$ 